\title{
Recognition of the Relevance of International Scientific Data: Poços de Caldas Geopark Project
}

\author{
Monteiro Vinícius Arcanjo \\ Institute of Geoscience, University of Campinas, São Paulo, Brazil \\ Email address: \\ viniciusmonteiro@ige.unicamp.br

\section{To cite this article:} \\ Monteiro Vinícius Arcanjo. Recognition of the Relevance of International Scientific Data: Poços de Caldas Geopark Project. International \\ Journal on Data Science and Technology. Vol. 7, No. 2, 2021, pp. 23-31. doi: 10.11648/j.ijdst.20210702.11
}

Received: January 7, 2021; Accepted: January 20, 2021; Published: June 23, 2021

\begin{abstract}
The scientific knowledge of geological sites is a model to recognize the scores of stablish geoconservation and education/touristic proposes sites in geoparks territories. The alkaline massif of Poços de Caldas is a structure of igneous alkaline origin (with volcanic and hypabissal deposits), formed, roughly, by breccias and tufts, effusive and hypabissal rocks and plutonic rocks. The purpose of this article is to recognize the international scientific relevance of geological sites in the Alkaline Massif of Poços de Caldas (Minas Gerais State) as a requirement to be a UNESCO Global Geopark. Poços de Caldas is located in the Southern region of Brazil and were know in the literature as the second biggest alkaline massif in the globe. We did a scientific database review in Scopus and manual review to recognize a science base for the issue of International publications of Poços de Caldas. The publication of bibliographic stuffs mentioned in the text formed a database for knowledge of international sites and its relevance. The themes of volcanism, hydrogeology, geomorphology, rare minerals and samples are contextualizing the geossites arranged in the article. The significance of largest igneous alkaline massif in the globe, rare minerals founded in Poços de Caldas, the uranium thematic in Brazil, the International Earth Science Olympiad and the hydrogeology are the main international relevant geossits in the region studied.
\end{abstract}

Keywords: International Value, Geosites, Geoheritage, Data Review, Geoscience

\section{Introduction}

The purpose of this article is to recognize the international scientific relevance of geological sites in the Alkaline Massif of Poços de Caldas (Minas Gerais State) as a requirement to be a UNESCO Global Geopark. According to Reinhold Ellert (1959) there is evidence of alkaline massif (of different origins) in the Kolla Peninsula (Russia), Poços de Caldas (Brazil), Itatiaia (Brazil), Ilimaussak (Greenland) and Pilanesberg (South Africa) and according to this comparative table, the second major feature (in the world) of this type of geological phenomenon is the structure known in the literature as the Alkaline Massif of Poços de Caldas - MAPC (Area $=800 \mathrm{~km}^{2}$ and diameter $=33 \mathrm{~km})$. MAPC is a structure of igneous alkaline origin (with volcanic and hypabissal deposits), formed, roughly, by breccias and tufts, effusive and hypabissal rocks and plutonic rocks [18]. At some point in evolutionary history, rocks were altered by hydrothermal fluid, which make them intensely mineralized from $\mathrm{Zr}, \mathrm{Mo}, \mathrm{Th}, \mathrm{TR}$ and $\mathrm{U}$ [1] a process concomitant with the formation of internal circular structures. MAPC is located in southeastern Brazil (Figure 1). The geological issue of the proposed area for geopark, involves in a small scale, the South American lithospheric plate, comprises a sequence of localized volcanic events, represented by alkaline rocks that form stocks, plugs, possible chimneys, dikes and exceptionally spills and pyroclastics known as the Alignment of Alkaline Rocks Poços de Caldas-Cabo Frio [41, 32].

These rocks have ages varying from the Upper Cretaceous to the Eocene and align in a WNW-ESE direction, in the State of Rio de Janeiro, and cut, in an oblique way, the preferential direction of the tectonic structures of the Ribeira Orogenic Band, from Precambrian age to Cambrian. Almeida [1] refers to these alkaline rocks as being predominantly felsic and represented mainly by nepheline syenite, pulaskito, foiaite, phonolite, tinguaite and trachite. Numerous studies have tried to interpret the origin of this alignment of rock bodies, preferably alkaline. Some of them, such as Herz, Cordani \& Teixeira, Sadowski \& Dias Neto, Fletcher \& Litherland, Fodor et al. and Gibson et al. suggested that these are periodic 
magmatic manifestations, when the movement of the South American lithospheric plate over a hot spot located possibly in the asthenosphere, during the phase of separation between the tectonic plates of South America and Africa [32, 41].
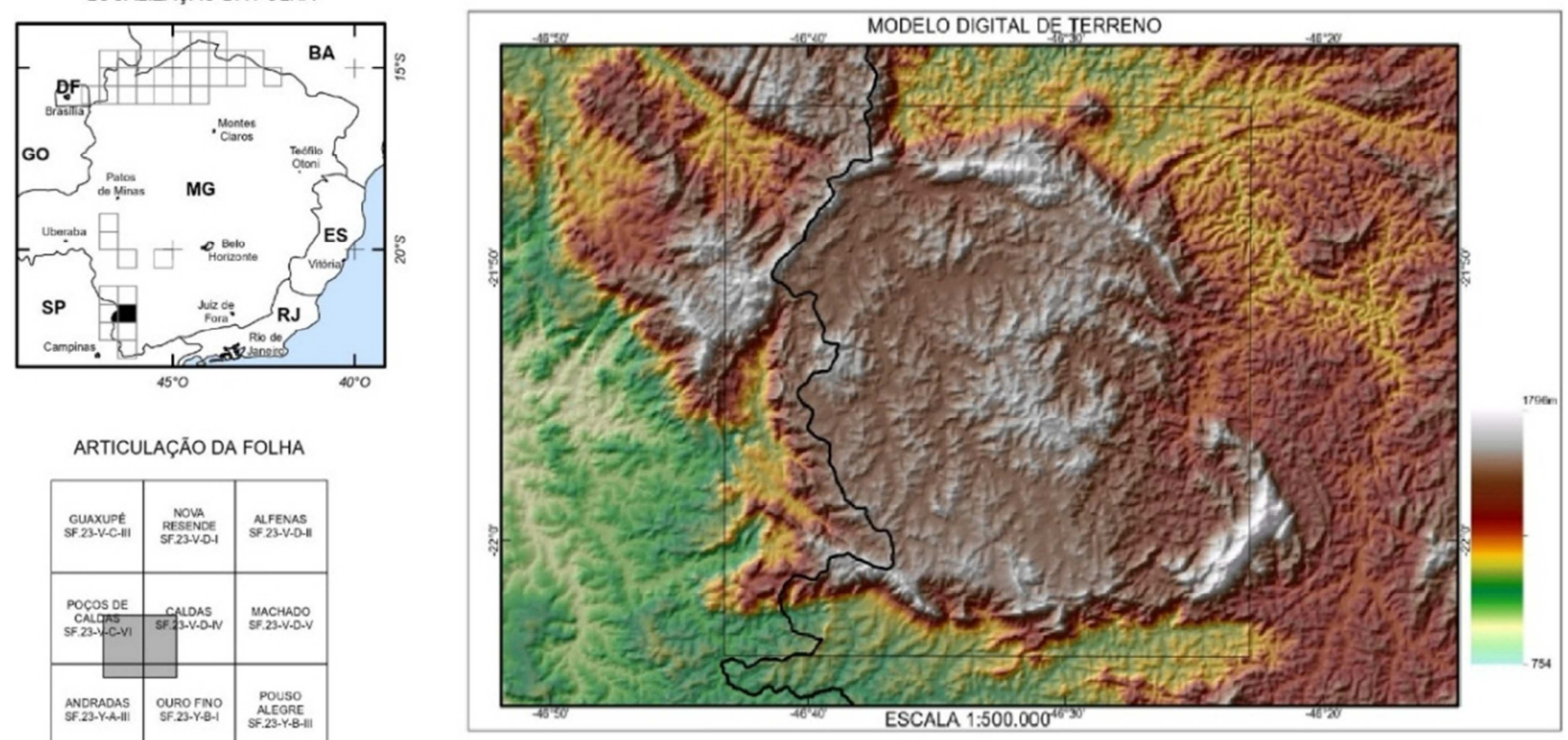

Figure 1. Location map od Alkaline Massif of Poços de Caldas. (Surface Digital Model, map articulation).

The pioneering study on geological outcrops in Poços de Caldas, is due to the work by Orville Derby (1859-1917) [30] entitled "On nepheline rocks in Brazil" of 1888 in a geological journal of London Society. From this year the first petrographic types were sent to the German petrologist Karl Heinrich Rosenbusche (1836 -1914), in Heidelberg, in which Derby refers to the study of the group of Philonian and Eruptive rocks. Rosenbusch who described the original tinguaite [43]. According to Willams [53]: "In 1888, Derby registers a "new birth certificate for the region" publishing the first scientific work on the mineralogy of the region, describing the alkaline rocks and the ring-shaped disposition". After some specific works between 1900 and 1932, the geology of the Poços de Caldas Massif was described by Ellert (19590 [18], who interpreted the first complete findings. The author developed one of the most important works on geology, both for its pioneering spirit and for the quality of the information provided. In his thesis entitled "Contribution to the Geology of the Alkaline Massif of Poços de Caldas", the author published the first geological map of the massif at a scale of 1:75,000 and described the main lithological types represented, in addition to presenting an account of the intrusion mechanisms and a volcanic caldera model with central subsidence, which was supported by studies by Björnberg [7] on the sedimentary rocks of the Poços de Caldas Plateau. The geological mapping works carried out by the National Nuclear Energy Commission (CNEN) in the years between 1960 and 1980 should also be highlighted. As well as the contributions of Resk Frayha [21] by the National Department of Mineral Production (DNPM), whose works were incorporated on the geological map. Later, the syenite nepheline bodies that were the object of cartography and studies detailed by Ulbrich [43] stand out. In addition to the evolutionary proposal and alkaline intrusion mechanism proposed by Ellert [18], some models were proposed by Motoki [28] called the Eroded Intrusive Body Model. And Bonotto [8] on the HotSpot mechanism.

The great amount of works available for consultation enabled and facilitated the elaboration of the MAPC geological heritage recognition inventory. Geological sites were identified based on the Strategic Approach [35] and were selected from the recognition inventory [27] and sought to relate the outcrops that: a) contained greater international scientific representation; b) had an international scientific reference; and c) revealed the geological (geochronology) and historical/cultural history (humans time) of the MAPC. The importance of this inventory for the Poços de Caldas scenario aims to provide geological data of the important geosites for contextualize the big history of Earth also highlight local culture. In addition to the academic-university circuit, the project uses information and communication as a 'driving force 'and their use in the public management for the territory covered. It presents as a differential the thesis that, geological matters geared to the geological heritage of the region [27] can be managed as educational through didactic-pedagogical treatments, sustainable development and protection strategies. In this article we will present which of the geosites inventoried in Poços de Caldas have international scientific relevance (requirement to be UNESCO World Geopark). 


\section{Methods}

\section{SCOPUS bibliometric database}

The search equation of the Scopus base is the structured formulation of the (Boolean) expressions of search parameters or keywords. They are search strategies about the type of information you want. In this double movement, in which the geological context of the MAPC is understood as the database for theoretical production, we were able to investigate continuities and ruptures in the scientific production process, as well as offer and enable bibliographic consultation methodologies of international relevance. The following combinations were used:

\# Search equation 1: (ALL (poços de caldas) AND ALL (geology)): 556 results.

In this first equation, all files related to the general research topic were searched with the following keywords: "Poços de Caldas" and "geology". This search showed 556 results in the publication interval between 1960-2016. The publications come mainly from Brazil, followed by surveys registered in the United States, France, England, Canada, among others. The institutions that carried out the most research were the University of São Paulo, UNESP, University of Rio de Janeiro, University of Brasília, University of Ouro Preto and British Geological Survey. The authors cited was Bonnoto, Mckinkey and Motoki (top three), among others. There is a domain of Earth and Planetary Sciences - 441 documents, followed by Environment Science - 146 documents. Four peaks in publications of related research being in the 1990s, in 2005, 2012 and 2015.

\# Search equation 2: (TITLE-ABS-KEY (poços de caldas) AND TITLE-ABS-KEY (geology)) AND (LIMIT-TO (SUBJAREA, "EARTH AND PLANETARY SCIENCY") OR LIMIT-TO (SUBJAREA, "ENVIRONMENTAL SCIENCE"

This equation had limited the search in two modes: (TITLE-ABS-KEY and LIMIT-TO), the first TITLE-ABS-KEY restricts the search only to search titles, abstracts and keywords; the second (LIMIT-TO) limits the search to the determined research area: Earth and Planetary Sciences and Environment Science. The analysis of the graphs represents the year of publication in the 1988 - 2014 interval. In this equation, the University of São Paulo and some North American Universities and authors such as Zuquetta, Alves, dos Santos and Lapido Loureiro stand out.

\# Search equation 3: (TITLE-ABS-KEY (poços de caldas) AND TITLE-ABS-KEY (environment)) OR (TITLE-ABS-KEY (sustainability) 33 resultados.

In this other equation, we searched for TITLE-ABS-KEY, which restricts the search only to titles, abstracts and search keywords. The search for the theme: "Poços de Caldas"; and (AND) Environment or Sustainability (Environment OR sustainability) peaked in 1996.

\# Search equation 4: (TITLE-ABS-KEY (poços de caldas) AND TITLE-ABS-KEY (geodiversity)) OR (TITLE-ABS-KEY (geoconservation) OR (TITLE-ABS-KEY (geoheritage). There is no research of this nature; this result justifies this article and its importance.

Bibliographical review of the inventory

The historiographical retrospective of scientific productions carried out during the process of the inventory [27]. Database was organized according to Ulbrich's [43] initial proposal, which separated scientific works by themes and authors, which are: a) geochronology; b) geotectonic interpretation; c) mineralogy and petrography; d) deposits of zircon and caldacite; e) uranium and molybdenum; f) thorium and iron; g) hydrothermal alteration and "potassic rocks"; h) bauxite and weathering. Some adjustments were made and included themes, such as the theme i) hydrogeology; extracted from the survey carried out through the work CETEC [13]. These themes provided us with an important overview of potential geosites, since many of them bring detailed descriptions of mineralogy, petrology, mineral deposits, geological evolution of the region and landscape formation processes. This selection also gave us an idea of the scientific productions in relation to periods of research and chronology of studies carried out in the area.

Geological map of the Geopark Poços de Caldas Project

The geosite identification in the Poços de Caldas territory was based on the Strategic Approach [35] which consists of a strategic and systematic survey of a specific area, identifying geoconservation target locations, with an approach that includes three different inventory methodologies: a) recognition: which consists of identifying significant features or places through bibliographic reviews, consultation with specialists and fieldwork; b) thematic and systematic: which is carried out from a comparative and interpretive assessment of all features and systems of a given region - georegional approach -; and c) details: in which a survey of specific information about the significance of geosites is made. This process led to the deferral of the Geological Map of the Poços de Caldas Geopark Project (Figure 2). Which summarizes the selected geosites.

\section{Results}

As shown in the mapping of the territory (Figure 2), after the Systematic Approach [35], 19 locations considered relevant in the geological scenario justified by scientific representativeness [11] and also by offering educational and tourist characteristics, aesthetic beauty, also were identified accessibility, among other parameters. Therefore, the distribution of geosites related to the organization of the geographic space (inventoried area) presents the places of relevant geological interest, seeking to relate the outcrops that: a) contained greater international scientific representation; b) had an international scientific reference; and c) revealed the geological history of MAPC. Of the 19 geosites, 13 locations have international scientific relevance, which will be presented as result below:

The Geosite "Parque Municipal da Serra de São Domingos" presents an important outcrop, known in the literature as "Pedra Balão". Northern edge (-2145 '39' 'South, -46³3' 23 " West) of the Poços de Caldas. It's a Khibinite-lujavrite bodie. 
It is a very peculiar place with a few large spherical boulders of lujavrite, hence the name Pedra Balão (= Balloon Stone). Protected in 1996 as a tourist attraction in Pocos de Caldas near to the town. Minerals samples come from the surrounding area - up to $900 \mathrm{~m}$ around the main outcrops. Pedra Balão is the type locality of manganoeudialyte and the reference comes from: Nomura, S. F et al. [29, 4, 5].

GEOPARQUE POÇOS DE CALDAS
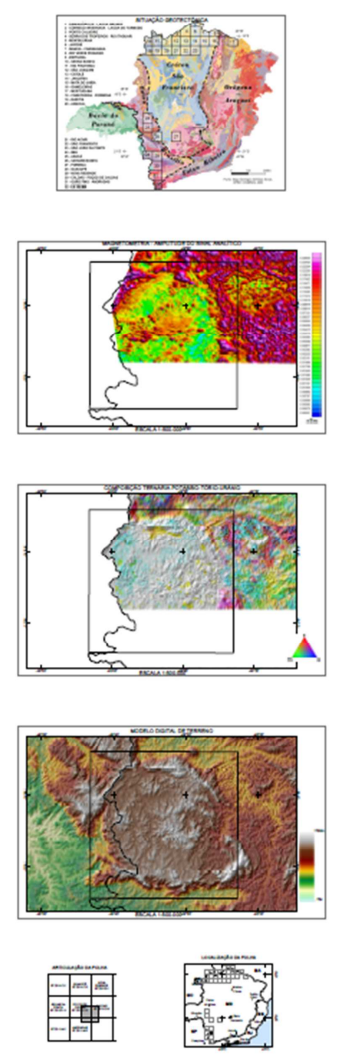

:
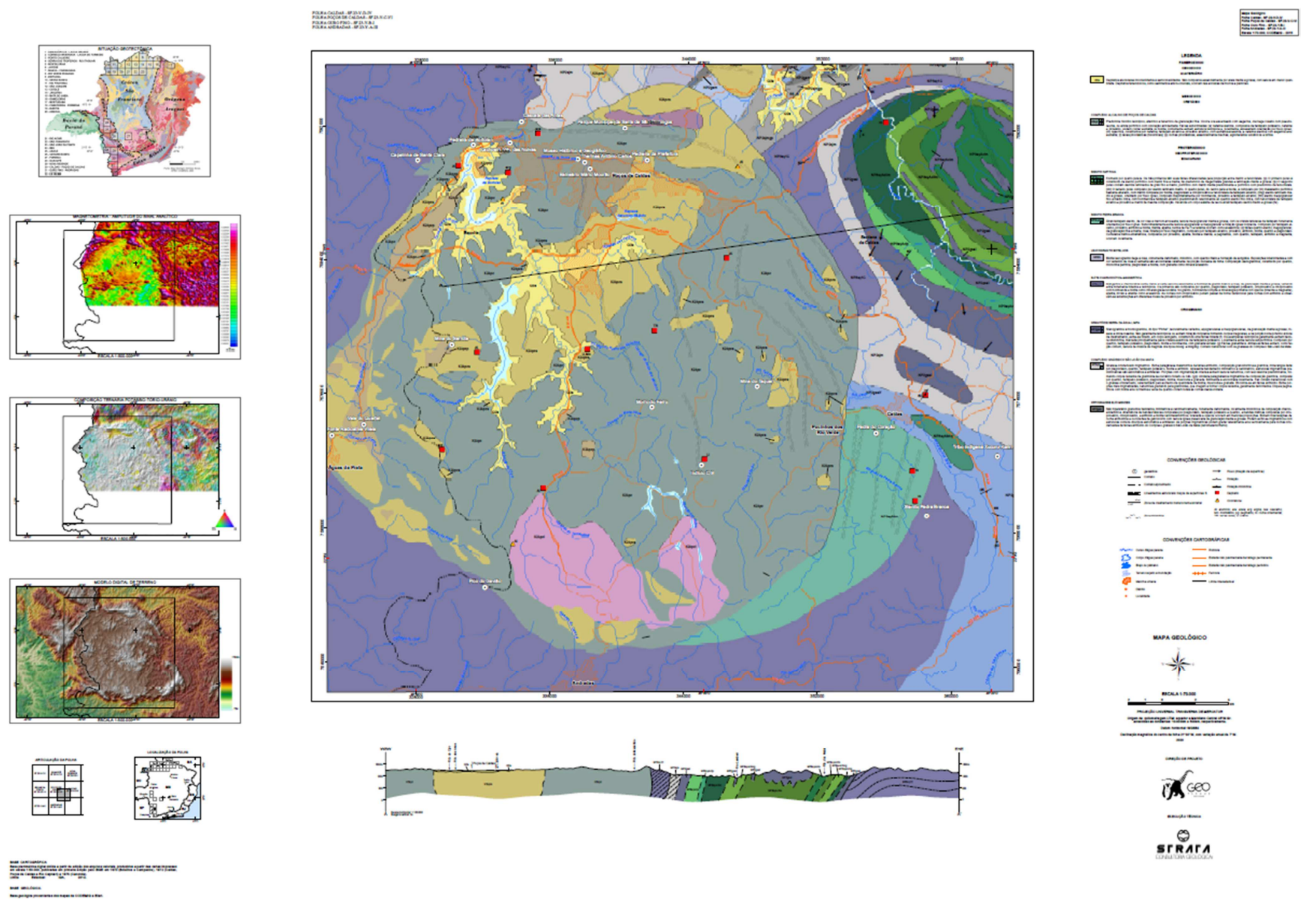

Figure 2. Geological Map of Geopark Poços de Caldas Project. Inedited. 2020.

The "Pedreira da Prefeitura" Geosite is part of the syenite nepheline bodies in the interior of the massif. This mine is located in the Serra do Selado (annular dike NE $\sim 1500$ meters), having been deactivated in 1992. The occurrence of the syenite nepheline in Pedreira is characterized by its stained appearance (gray and whitish feldspars). phaneritic (macroscopic texture) of the Plateau; it appears loaded with tinguaite enclaves, close to the contacts. Mineralized (narrow) veins in syenite nepheline have interesting minerals, e.g.: Gaidonnayite and Hilairite. The main bibliographic references about this syenitic body then in $[43,33,36]$.

The "Thermas Antônio Carlos" Geosite is of interest to hydrogeology. The source of hot sulphurous water is located in the homogeneous urban region at an altitude of 1200 meters. The fountain called Pedro Botelho supplies Thermas Antônio Carlos. Sulfurous water has a natural appearance in depth (> 260 meters) and percolates the fracture $\mathrm{N} 14^{\circ} \mathrm{E}, \mathrm{N} 50^{\circ} \mathrm{E}$ and $\mathrm{EW}$, at an average temperature of $45^{\circ}$ and 30 thousand liters / hour. A pumping system takes the water to the Thermas Antônio Carlos Building. The classification of water, according to the National Department of Mineral Production
(DNPM) is: hyperthermal, alkaline, sodium bicarbonate and sulfur dioxide, slightly radioactive. The Thermas Antonio Carlos building is a construction and historical and cultural heritage of the municipality and the main tourist attraction and stands out, in the context of the hydrothermal estancias of Latin America [14-16].

The mineralogical collection of the Geosite "Historical and Geographic Museum of Poços de Caldas - Samples of minerals, rocks and ores from Resk Frayha Room" is a permanent exhibition of 134 samples (ex-situ), presented by name and origin, of the rocks, minerals and ores from the Poços de Caldas Massif. This collection belonged to Resk Frayha, an engineer from the National Department of Mineral Production (DNPM), whose scientific works have regional, national and international relevance. In 1962, Resk Frayha published the report "Uranium and Thorium in the Poços de Caldas Plateau" which contains descriptions of radioactive anomalies in the region. Resk Frayha discovered uranium in the caldasito in Poços de Caldas, which was later studied by the American Geological Survey and intensified years later with the installation of the first Nuclear Plant in Brazil. The 
samples of rocks, minerals and ores present in this rich collection point to the massif's geodiversity and relevance on the international stage. The museum's technical reserve still holds 140 other samples of rocks, minerals and ores, which are not on display. The Museum has a library with rare publications on the history of Poços de Caldas and permanent exhibitions with the purpose of presenting furniture, belongings, etc., which portray the history of the municipality. The house that became a museum is a heritage site for the municipality's historical and cultural heritage.

The "Mina do Taquari" Geosite is located on the east side of the massif. There is one of the oldest zirconium mines explored in the region. The radioactivity of Taquari is associated with caldasito and the rock that constitutes the hill that supports the zirconium deposit. The vein of uraniferous syrup from "Morro do Taquari" (=Taquari Hill) occurs embedded in a foiaite intensely altered by the hydrothermal action. It also presents, in depth, secondary remineralization with the presence of pyrite crystals and veins of fluorite (violet in color). This area is about 170 hectares. This geosite has an open gallery at an altitude of 1380 meters towards the top of "Morro do Taquari", with opening dimensions of $2.20 \mathrm{x} 1$ and an extension of $\sim 100$ meters. Relevant works were published and among them $[39,40]$.

The "Syenite Pedra Branca" Geosite presents a "truncated" feature to the alkaline ring dike, represented by a post-orogenic magmatism. Its origin ca. $610 \mathrm{Ma}$. Would have occurred as a response to the lateri-collisional mass lateral escape process, associated with alkaline magmatism. Which can be explained by an isotopic signature associated with partial fusion of enriched lithospheric mantle horizons, which occurred after an important vertical displacement of Nappe Socorro-Guaxupé (after major metamorphism), these would then result in crystallization of K-rich magma originated at the base of the lithospheric mantle, by the percolation of molten material, either from the asthenospheric mantle or by subduction. It is a rock with an area of $90 \mathrm{~km}^{2}$ made up of syenite alkali-feldspar, medium to thick uneven texture, with feldspar crystals strongly oriented by a beige-pink to brown-gray fiery flow. In older works (ex: Ellert, 1959) this rock was considered the gneiss of the metastasized crystalline basement by alkaline fluid, originating the phenyto. There is mining in NE of the ornamental stone area: the "Coffe Syenite" (brown syenite), nationally known and presented as an example in the igneous nomenclature of the International Union of Geological Sciences (IUGS). Proposed Environmental Protection Area (APA) are being implemented in this geosite $[38,54]$

The "Morro do Ferro" Geosite practically occupies the geographic center of the alkaline intrusion and is constituted by a conspicuous hill, whose altitude is 1540 meters, historically known as "top of the consultation". The geological nature of this geosite is of a "sui generis" order, there is no knowledge of other similar deposits anywhere in the world. The entire mass is mineralized and presents weathering and hydrothermal changes - only the magnetite is individualized. The syenitic rock is reworked and remineralized, generating a clay with iron oxides. The area has been exploited economically since 1954, consisting of a "stockwork" (dyke) of magnetite, thorium and rare earths. In the mineralized body, water circulation cracks occur from the surface to the depth, forming fields more enriched with thorium concentration. Morro do Ferro ore has a high concentration of rare earths, with a predominance of cerium, lanthanum, neodymium and praseodymium. In the geosite there is a gallery in the longitudinal direction, 210 meters long, which proves the $\mathrm{ThO}_{2}$ content in the mineralized mass and surface radioactivity (down to 25 meters in depth). This geosite was one of the most studied anomalies, the main references are: [50-52, 21, 25, 20, 22, 39, 40, 6, 47, 48, 33, 9]

The "Indício C-09" Geosite is where Osamu Utsumi Uranium Mine is located. In 1952 the "Caldasito" ${ }^{1}$ of Poços de Caldas was classified as a uranium ore and, until 1962, 22,000 tons were explored in Poços de Caldas by the National Nuclear Energy Company in cooperation with the United States Geological Survey at the Osamu Utsumi Mine. Poços de Caldas, however, was the first mining district in Brazil to explore uranium. Historically known as C-09 evidence, Campo do Cercado is located to the south of the alkaline intrusion, in the upper course of Rio das Antas. It is the most extensive area indicated by the aeroscintilometric survey of radioactive anomaly. It is a surface material in outcrops, a manganese gravel. Very similar to that found in Morro do Ferro and also thorium and rare earths, about 1 meter deep. Up to firm rock, about 65 meters, the borehole indicated the phonolite rock altered by hydrothermal actions. In area A, of this field, there is a gallery and secondary galleries with approximately 120 meters in length, propped with sawn hardwood and the roof covered with 2 'wooden planks. International publications are at: [39, 40, 12, 49].

"Pedreira do Bortolan" Geosite is an abandoned quarry since 1992 located in the West zone at the head of the ring dike, near the Bortolan Dam. This geosite presents relevant petrographic interest with variations of tinguaito and volcanic and mineralogic breaches (geodiversity of 37 mineral species) presenting rare minerals from Poços de Caldas, such as: villiaumita, Hainite and Tuperssuatsiaite. Substantial references on mineralogy are in: $[10,46,23,44,33,36,34,45$, 26, 2, 3].

The "Mina do Serrote" Geosite is a hill (1340 meters high) occupying an extensive area on the western edge of the massif, where there are numerous veins of embedded uranium syrup and a completely altered syenite. On the surface it presents a gravel-zirconiferous. The Serrote Mine was one of the most important sources of zirconium in Poços de Caldas, with high content and extension. There is a caldasito block in the Serrote Mine, preserved by the National Department of Mineral Production, as a mineralogical monument, consisting of a single stone weighing about 40 tons. This block, disaggregated from some shaft, has a zirconium oxide content of $80 \%$ and $1 \%$ uranium oxide. This geosite presents a rare mineral of international relevance, Fluorlamprophyllite -

1 Regional name 
chemical formula: $\mathrm{Na}_{3}(\mathrm{SrNa}) \mathrm{Ti}_{3}\left(\mathrm{Si}_{2} \mathrm{O}_{7}\right)_{2} \mathrm{O}_{2} \mathrm{~F}_{2}$ - discovered in 2013 and registered with the IMA (International Mineralogical Association). [20, 43]

The "Vale do Quartel" Geosite is a pyroclastic valley of petrographic and structural interest. This eruptive strip has as its particularity the historical study of Orville Derby (1887), entitled "On the nepheline rocks of Poços de Caldas" considered the "geological certificate of the region" and the first published geological work. Vale do Quartel represents the pyroclastic band related to the initial sub-aerial volcanism. These materials are related to the formation of the main circular structure of the massif, when the subvolcanic chamber collapses. Gaps and volcanic clusters, annealed sandstone, tuffites, agglomeratic lava, tinguaite gaps and fragments of ankaratritic lava are the main outcrops found along the valley. It is a notable band of pyroclastic rocks, which, with the shape of an arch, accompanies the outcrops of the western ring, from the vicinity of Ponto da Cascata, until the end of Vale da Fonte Platina, the S (little to the NE of Águas da Prata). The strip has a length of about $20 \mathrm{~km}$ and a width that varies from 1-2 to 4 $\mathrm{km}$, almost entirely composed of pyroclastic rocks, the strip is related, $\mathrm{N}$ and $\mathrm{S}$, with sandstones along the Valley of the Barracks. This area is a political landmark of State territorial demarcation between São Paulo and Minas Gerais, ended (1932) with the monument Marco Divisório. Some waterfalls are tourist attractions in this area.

The "Fonte Radioativa Vilela" Geosite emerges at the foot of a wall about $10 \mathrm{~m}$ high, almost at the top of the sandstone capping cliff covered by the locally called "Mata da Prata" natural forest. In this very silicified sandstone, slight folding is noted, traces of a pushing force from the underlying intrusive layers. The water springs from the sandstones through open fractures in the vertical and horizontal directions. It is analyzed as a strongly radioactive water due to the yellowish clay material, associated with zirconium, in the rock with about $0.2 \%$ uranium oxide [37].

\section{Discussion}

Throughout this article, some themes are covered, focused on the systemic breadth of geology. At the beginning, these are more general questions about understanding the geological context of the Alkaline Massif, but we must pay attention to the factor of international geological heritage. But, before reaching the concluding notes on this topic, it is necessary to contextualize (roughly) what is happening on the environmental issue in Brazil. We scientists are following what is happening in the environmental area in Brazil, the general dismantling, this is also happening in other areas of the Federal Government, but particularly in the area of the Environment. And, due to the fact that it does not have any "bigger dimension", it ends up not occupying space in the press and in the discussion of the interested people, but there is a great dismantling in the environmental system that come from two great movements that is the privatization of National parks, this, it must be said, it is not just a change of boxes but it is a return to a utilitarian vision, so it is turning to a concept of disasters in the Brazilian policies of the $60 \mathrm{~s}$, 70s of very fast development (urbanization) and the Environmental Project is now with a vision of use and not as a vision of sustainability, obviously, where the 2030 progression this symbolism would be much more present. And it has a disassembly, too, for the security of these natural limits in relation to agribusiness, which modifies and makes all legislation responsible, including reproducing in other states of the nation. This is a problem in the Brazilian case, starting with the impact it has on territories and geopark projects, it is clear that it deals with the concession, but in fact it is a concession for some years, so how does the utility tourism market work in the view of the State (?). This gradually leads to a process of privatization of 'Nature' in Brazil, because when we talk about the privatization of national parks we are talking about companies... When you define a territory along the lines of a geopark, you define that geology, culture and tourism has a condition for framing the future, even if it does not have this condition in the present reality, but that society can sustainably manage this territory. And, in the State project, he says the following: it doesn't matter any of that, if the company that is bidding to manage the territory or park, does not have payment conditions, you cannot launch your application due to the so-called payment capacity of the user, so there are several things there that never fit properly between the environmental sector and the tourism sector, although in the general spirit, you have to articulate the management plan with the water resources plan (for example), with the plan director, with the economic-tourist plan but in practice these things do not happen. It is foreseen in the Federal Constitution that it allows through public consortia the list of federated entities that allows a municipality, states and the Union to transfer the execution of its management to a public company, without bidding, through the program contract. So, some National Laws introduce, but do not affect the privatization process, it creates a favorable environment for privatization and this environment is motivated by central instruments: 1 . Prevent the municipality from entering into a program contract, that is, the program contract has ended; then any transfer of service has to be done by bidding (where a public company can participate) and 2. It fragments state companies, in such a way that the provision of regionalized service is the priority organization. In the case of Poços de Caldas, the bidding for a tourism sector venture is not entirely bad (and it is already underway), because it has two things, in my opinion, that are important, one is unreal, but it is very good that has a lot though, I think it was done the wrong way, Brazil is extensive (as we already learned at school) and Brazil is very unequal, but he establishes that new contracts will have to have goals, including the old ones, they will have to be adjusted to have goals. And these goals are to rebuild public assets. This is good, but it is not viable. Unviable because if you take here Poços de Caldas, the southeastern region, it is not very close to reaching the economic return target foreseen by the bidding process, but instead it will suffer a tariff impact to cover these goals that is impossible to be sustained. But even with these mistakes the question of having goals seems to 
me a positive one indeed. The second thing that I consider to be positive, not always the sectors of the left in which I work, agree with this, which is to define that we will have a national regulatory agency responsible for setting reference standards for geoparks, today the Geological Service, but soon, also the Directory of the National Secretariat of Tourism and the Itamaraty (Unesco-Brasil), for example, and that are still important themes in the international scenario of geosciences, including UNESCO position.

\section{Conclusions}

The problem was identified at the national level and it directly affects or complements the Geopark Project in Poços de Caldas (regional scale). It is concluded, in this article, that all policy related to bidding processes for ecological, cultural and historical tourism enterprises, are based on these methodological processes, as this inventory presented, from the strategic approach presented in detail.

This article, which also occurs in the form of a manifesto, focuses on substantial characteristics of international geological heritage in Poços de Caldas, which have already been presented as results, but which are worth reiterating in this part of the text. Since:

1. The Poços de Caldas Alkaline Massif is the second largest alkaline massif in size on the globe;

2. Themes of international representativeness in the teaching of geosciences are possible approaches in the territory of the Poços de Caldas Geopark: geochronology; geotectonic interpretation; mineralogy and petrography; zircon deposits; uranium and molybdenum; thorium and iron; hydrothermal alteration; bauxite and weathering; hydrogeology.

3. Discoveries of rare minerals were found in Poços de Caldas with international representativeness (See Geosites: "Municipal Park of Serra de São Domingos"; "Pedreira da Prefeitura"; "Mina do Taquari"; "Pedreira do Bortolan"; " Mina do Serrote "; " Indício C-09 "and" Morro do Ferro ")

4. The uranium theme in Poços de Caldas has national historical relevance and support from international geological agencies (See Geosite "Indício C-09" and "Morro do Ferro");

5. Radioactive waters have materials superior to cold mineral waters from any part of the globe (see Geosite Fonte Radioativa Vilela);

6. The geological evolution of the MAPC is recurrent in the international literature (see Geological Map of the Geopark Poços de Caldas and literature below);

7. The Poços de Caldas geodiversity is presented in collectible samples of international and local relevant cultural, historical and geological interest (see Geosite "Poços de Caldas Historical and Geographic Museum");

8. The city of Poços de Caldas is already known as emblematic national tourist destination;

9. The International Earth Science Olympiad (IESO-2015) occur in 2015 in MAPC and geosites were used by the students as practices test; (educational approach tested by International Geoscience Education Organization IGEO).

\section{References}

[1] Almeida filho R. (1977) Estudo do maciço alcalino de Poços de Caldas através de imagens LANDSAT com ênfase em mineralizações radioativas. Tese de Mestrado. Relat. INPE. 1112-TPT/065, $130 \mathrm{p}$.

[2] Atencio, D., Coutinho, J. M. V., and Vlach, S. R. F. (2005) Tuperssuatsiaite from the Bortolan quarry, Poços de Caldas, Minas Gerais, Brazil. Mineralogical Record, 36, 275-280.

[3] Atencio, D., Coutinho, J. M. V., Ulbrich, M. N. C., Vlach, S. R. F., Rastsvetaeva, R. K., and Pushcharovsky, D. Y. (1999) Hainite from Poços de Caldas, Minas Gerais, Brazil. The Canadian Mineralogist, 37, 91-98.

[4] Baptista, A. (1976) Lamprofilita no lujaurito de Pedra Balão, Poços de Caldas, Minas Gerais. Lamprophyllite in the lujavrite of Pedra Balão, Poços de Caldas, Minas Gerais.] Annaes da Academia Brasileira de Ciências, 48 (3), 193-196 (in Portugese).

[5] Baptista, A. (1980) Estudio radiocristografico da Eudialita de Pedra Balao, Poços de Caldas, Estado de Minas Gerais. [Radiocrystallographic study of eudialyte from Pedra Balao, Poços de Caldas, Minas Gerais.] Annaes da Academia Brasileira de Ciências, 52 (2), 243-250 (in Portugese).

[6] Baretto, P. M. C. and Fujimori, K. (1986) Natural analogue studies: geology and mineralogy of Moro do Ferro, Brazil. Chemical Geology, 55, 297-312.

[7] Björnberg, A. J. S. (1959) Rochas clásticas do Planalto de Poços de Caldas. Boletim da Faculdade de Filosofia, Ciências e Letras da Universidade de São Paulo, São Paulo. 237.

[8] Bonotto, D. M. (2010) The Poços de Caldas Hot Spot. A Big Blast for Nuclear Energy in Brazil. Nova Science Publisher, Inc. New York. 234 p.

[9] Bonotto, D. M., Fujimori, K., and Moreira-Nordemann, L. M. (2007) Determination of weathering rate of the Morro do Ferro Th-REEs deposit, Brazil using U-isotope method. Applied Radiation and Isotopes, 65, 474-481.

[10] Ellert, R. (1969) Nota sobre a ocorrencia de villiaumita do maciço de Poços de Caldas, M. G. [The occurrence of villiaumite in the Poços de Caldas massif, M. G.] Mineração e Metalurgia, 49 (294), 234 (in Portuguese).

[11] Brilha, J. B. R. (2016) Inventory and Quantitative Assessment of Geosites and Geodiversity sites: a Review. Geoheritage. The European Association for Conservation of Geological Heritage. Springer.

[12] Cathles, L. M. and Shea, M. E. (1992) Near-field high-temperature transport: evidence from the genesis of the Osamu Utsumi uranium mine, Poços de Caldas alkaline complex, Brazil. Journal of Geochemical Exploration, 45 (1-3), 565-603.

[13] CETEC. (1987) Avaliação hidrogeológica e hidroquímica dos arredores de Poços de Caldas. Fundação Centro tecnológico de Minas Gerais. Belo Horizonte. 
[14] Cruz, W. B. \& Peixoto, C. A. M. (1989). As águas termais de Poços de Caldas, MG - estudo das interações água-rocha. Rev. Bras. Geoc., v. 19, n. 1, pp. 76-86.

[15] Cruz, W. B.; Peixoto, C. A. M.; Pimentel, M. L. (1987) Avaliação hidrogeológica e hidrogeoquímica dos arredores de Poços de Caldas. CETEC. Belo Horizonte/MG.

[16] Cruz, W. B. \& Pimentel, C. A. M. (1991). A evolução química das águas subterrâneas de Poços de Caldas - MG. Revista Brasileira de Geociências.

[17] De Lima, J. L. N.; Bonotto, D. M. Etapas analiticas para mensuracao de radonio-222 e uso na avaliacao da radioatividade das aguas de Aguas da Prata (sp). Geochimica Brasiliensis, v. 10, n. 2, p. 283-295, 2017.

[18] Ellert R. (1959) Contribuição à Geologia do Maciço Alcalino de Poços de Caldas. Tese (Doutorado) Faculdade de Filosofia, Ciências e Letras. Universidade de São Paulo.

[19] Ellert, R.; Björnberg, A. J. C.; Coutinho J. M. V. (1959) Mapa Geológico do Maciço Alcalino de Poços de Caldas. 1:50.000 Departamento de Geologia e Paleontologia - F. F. C. L. Instituto de Geociências. USP.

[20] Franco, R. R. and Loewenstein, W. (1948) Zirconium from the region of Poços de Caldas. American Mineralogist, 33, 142-151.

[21] Frayha, R. (1962) Urânio e Tório no Planalto de Poços de Caldas. Departamento Nacional de Produção Mineral.

[22] Frondel, C., and Marvin, U. B. (1959) Cerianite, $\mathrm{CeO}_{2}$, from Poços de Caldas, Brazil. American Mineralogist, 44, 882-884.

[23] Fujimori, K. (1982) Silicato do terras raras (Ce, La, Nd, Ca, $\mathrm{Th}) \mathrm{SiO}_{4}$ e cheralita $(\mathrm{Th}, \mathrm{Ca}, \mathrm{Ce}, \mathrm{La})\left(\mathrm{PSiO}_{4}\right)$. Annaes XXXII Congress Sociedade Brasileira de Geologia, Boletim 2, 669-671 (in Portuguese).

[24] Garda, G. M; (1990) A alteração hidrotermal no contexto da evolução geológica do maciço alcalino de Poços de caldas. Tese. Universidade de São Paulo. 213 p.

[25] Hussak, E. and Reitinger, J. (1903) Xenotim, Senait und natürliches Zirkonoxyd aus Brasilien. Zeitschrift für Krystallographie und Mineralogie, 37, 566-574 (in German).

[26] Matioli, P. A., Atencio, D., and Tsugawa, J. K. (1998) Recent contributions to the mineralogy of Poços de Caldas alkaline massif, Minas Gerais, Brazil. Abstracts with Program, 17th General meeting of the International Mineralogical Association, Toronto, Canada, A111.

[27] Monteiro, V. A. Inventário de reconhecimento do Patrimônio Geológico do Maciço Alcalino de Poços de Caldas, divisa SP/MG. 2018. (270 p.). Dissertação (mestrado) - Universidade Estadual de Campinas, Instituto de Geociências, Campinas, SP. Disponível

em: http://www.repositorio.unicamp.br/handle/REPOSIP/331417. Acesso em: 3 set. 2018.

[28] Motoki, A; Vargas T.; Chianello E.; Correa F. J. G; Oliveira J. L. S.; Klotz M. (1988) Nível de denudação atual do Complexo Alcalino de Poços de Caldas (MG/SP). Departamento de Geologia/Geofísica da Universidade do Estado do Rio de Janeiro - UERJ. Boletim de Congresso Brasileiro de Geologia.
[29] Nomura, S. F., Atencio, D., Chukanov, N. V., Rastsvetaeva, R. K., Cutinho, J. M. V., and Karipidis, T. K. (2010) Manganoeudialyte, a new mineral from Poços de Caldas, Minas Gerais, Brazil. Zapiski Vserossiiskogo Mineralogicheskogo Obshchestva, 139 (4), 35-47.

[30] Orville A. Derby. On Nepheline-Rocks in Brazil, with Special Reference to the Association of Phonolite and Foyaite. Quarterly Journal of the Geological Society, 43, 457-473, 1 February 1887.

[31] POÇOS DE CALDAS. (2010) Prefeitura Municipal e Departamento de Meio Ambiente. Plano de Manejo do Parque Municipal da Serra de São Domingos. UFLA. Lavras (MG).

[32] Sadowski E DIAS NETO (1981). O lineamento sismo-tectônico do Cabo Frio. Rev. Bras. Geoc., 11 (4): 209 212 .

[33] Schorscher, H. D. and Shea, M. E. (1992) The regional geology of the Poços de Caldas alkaline complex: mineralogy and geochemistry of selected nepheline syenites and phonolites. Journal of Geochemical Exploration, 45, 25-51.

[34] Schumann, A. (1993) Changes in mineralogy and geochemistry of a nepheline syenite with increasing bauxitization. Chemical Geology, 107 (3-4), 327-331.

[35] Sharples, C. (2002). Concepts and principles of geoconservation. Tasmanian Parks \& Wildlife Service. Disponível em: http://dpipwe.tas.gov.au/Documents/geoconservation.pdf Acesso em janeiro de 2018.

[36] Shea, M. E. (1992) Isotopic geochemical characterization of selected nepheline syenites and phonolites from the Poços de Caldas alkaline complex, Minas Gerais, Brazil. Journal of Geochemical Exploration Volume 45, Issues 1-3. p. 173-214.

[37] Szikszay, Mária; Teissedre, Jean-Marie. Fontes da estância de Águas da Prata, estado de São Paulo. Boletim IG, v. 8, p. 83-95, 1977.

[38] Tedeschi M. F., Novo T. A. Azevedo R. A., Amaral L. F. S., Degler R., Vieira P. L. N. C. R. 2015. Mapa geológico: Folha Caldas SF. 23-V-D-IV, Folha Poços de Caldas SF. 23-V-C-VI, 1:100.000. In: Projeto Fronteiras de Minas, Belo Horizonte, UFMG-IGC-CPMTC-CODEMIG.

[39] Tolbert, G. E. (1966) The uraniferous zirconium deposits of the Poços de Caldas Plateau, Brazil. U.S. Geol. Surv. Bull. 1185-C, $28 \mathrm{p}$.

[40] Tolbert, G. E. (1966) The Uraniferous Zirconium Deposits of the Poços de Caldas Plateau, Brazil. United States Geological Survey Bulletin 1185-C, 28 pp. and maps.

[41] Tomaz-Filho, A. \& Rodrigues, A. L. (1999) O alinhamento das rochas alcalinas de Poços de Caldas - Cabo Frio (RJ) e sua continuidade na cadeia Vitória- Trindade. Revista Brasileira de Geociências. 29 (2): 189-194, junho.

[42] Tosatto, P. (2001) Orville A. Derby "O Pai da Geologia do Brasil" - DNPM - Museu de Ciências da Terra; CPRM Serviço Geológico do Brasil.

[43] Ulbrich, H. H. G. J. (1984) A petrografia, a estrutura e o quimismo de nefelina sienitos do Maciço Alcalino de Poços de Caldas, MG - SP. (Livre Docência). Instituto de Geociências, Universidade de São Paulo, São Paulo. 1984. 
[44] Ulbrich, M. N. C. (1986) K-feldspars from Poços de Caldas nepheline syenites, southern Brazil: chemical, optical and XRD studies. Annaes da Academia Brasileira de Ciêncas, 58, (1), 166.

[45] Ulbrich, M. N. C. (1993) Mineralogy of nepheline syenites from the Poços de Caldas alkaline massif SE Brazil: chemistry, $\mathrm{X}$-ray data and microtextures of feldspars Revista Brasileira de Geociencias, 23, 388-399.

[46] Ulbrich, M. N. C., Gomes, C. B., and Ulbrich, H. (1980) Zonalidade extrema nos piroxenios do nefelina sienito hibrido de Pocos de Caldas - MG. [Extreme zonality in pyroxenes of the hybrid nepheline syenite of Pocos de Caldas, Minas Gerais.] XXXI Brazilian geological congress; Bulletin No. 2, Abstracts. 420 (in Portuguese).

[47] Waber, N. (1991) Mineralogy, petrography and geochemistry of the Poços de Caldas analogue study sites, Minas Gerais, Brasil; Morro de Ferro. Universitats Bern, Mineralogisches Petrographisches Institut, SKB Technical Report, No. 90-12, $110 \mathrm{pp}$.

[48] Waber, N. (1992) The supergene thorium and rare-earth element deposit at Morro do Ferro, Pocos de Caldas, Minas Gerais, Brazil. Journal of Geochemical Exploration, 45, 113-57.
[49] Waber, N., Schorscher, H. D., and Peters, T. (1992) Hydrothermal and supergene uranium mineralization at the Osamu Utsumi mine, Poços de Caldas, Minas Gerais, Brazil. Journal of Geochemical Exploration, 45 (1-3), 53-112.

[50] Wedow, H. (1961) Laterization of allanite in the Morro do Ferro rare-earth and thorium deposit, Poços de Caldas Plateau, Brazil. Economic Geology, 56 (7), 1315.

[51] Wedow, H. (1961) Thorium and rare earths in the Poços de Caldas zirconium district, Brazil. United States Geological Survey Professional Paper 424-D, 214-216.

[52] Wedow, JR. H. (1967) The Morro do Ferro thorium and rare-earth ore deposit, Poços de Caldas district, Brazil. U.S. Geol. Surv. Bull., 1185-D, 34p.

[53] Williams, D. (2001) Memorial da Companhia Geral de Minas, Subsidiária da Alcoa Alumínio S/A: seus 65 anos (1935-2000). História da Mineração em Poços de Caldas.

[54] Winters, A. A. M. (1981). Geologia do maciço sienítico da Pedra Branca, Caldas-MG (Doctoral dissertation, Universidade de São Paulo). 